\title{
A case of retropharyngeal foreign body causing meningitis
}

\author{
Menenjite neden olan retrofarengeal yabancı cisim olgusu
}

Gökhan Kutlar

Department of Otolaryngology, Medical Faculty of Ondokuz Mayıs University, Samsun, Turkey

\begin{abstract}
Foreign bodies in the retropharyngeal space leading to meningitis are rare. In this article, we report a 58-year-old male patient who had been suffering from neck pain for two months. Patient's retropharyngeal space appeared bulky on indirect laryngoscopy. Computed tomography of the neck showed thickening of the retropharyngeal space and a foreign body. The patient was performed lumbar puncture due to deterioration of consciousness and temperature up to as high as $40{ }^{\circ} \mathrm{C}$. Intravenous antibiotic treatment was started with diagnosis of meningitis and retropharyngeal abscess. No reproduction occurred in cerebrospinal fluid and blood cultures. However, the patient died on the second day of treatment. In this article, we want to emphasize that delayed diagnosis and treatment of retropharyngeal space infections can be fatal.
\end{abstract}

Keywords: Foreign body; meningitis; retropharyngeal abscess.

Retropharyngeal space infections may manifest as a life-threatening abscess or cellulitis. ${ }^{[1]}$ They are common in children and are often secondary to tonsillitis and pharyngitis. In adults, foreign bodies (i.e. chicken bone, fishbone, and oral prosthesis), pharyngeal or esophageal trauma, and surgical operations are prominent. ${ }^{[2]}$ Individuals with diabetes mellitus or suppressed immunity are at risk for these infections. ${ }^{[3]}$ The most significant symptoms include neck pain, dysphagia, and respiratory distress. Retropharyngeal space infections can cause airway obstruction, mediastinitis, sepsis, pleural empyema, or, in rare cases, central nervous system infections (such as meningitis, epidural abscess, and brain abscess). ${ }^{[2,4]}$
Retrofarengeal bölgede menenjite yol açan yabancı cisimler nadirdir. Bu yazıda, iki aydır boyun ağrısı çeken 58 yaşında bir erkek hasta sunuldu. İndirekt laringoskopide hastanın retrofarengeal bölgesi dolgun görünümdeydi. Boyun bilgisayarlı tomografisinde retrofarengeal bölgede kalınlaşma ve yabancı cisim izlendi. Bilincinin bozulması ve $40{ }^{\circ} \mathrm{C}$ 'ye varan yüksek ateşi nedeniyle hastaya lomber ponksiyon yapıldı. Menenjit ve retrofarengeal apse tanılarıla intravenöz antibiyotik tedavisi başlandı. Beyin-omurilik sıvısı ve kan kültürlerinde üreme olmadı. Ancak hasta tedavinin ikinci gününde kaybedildi. Bu yazıda, retrofarengeal bölgedeki enfeksiyonların tanı ve tedavisindeki gecikmenin ölümcül olabileceğini vurgulamak istedik.

Anahtar sözcükler: Yabancı cisim; menenjit; retrofarengeal apse.

We report the case of an adult with a foreign body lodged in his retropharyngeal space that led to meningitis due to delayed diagnosis.

\section{CASE REPORT}

A 58-year-old male patient had been suffering from neck pain for the past two months. The pain had worsened within the last few days, and he thus visited our neurosurgery department. His medical history included cervical hernia for which he was undergoing physiotherapy. He had no chronic diseases or suppressed immunity. In addition, he had undergone esophagoscopy at an otorhinolaryngology clinic two months ago for a 
chicken bone that was stuck in his throat but no foreign body was found.

The patient appeared agitated during the examination, and was not fully cooperative. He was unable to extend his neck. He did not have any focal neurological deficits. His retropharyngeal space appeared to be slightly bulky on indirect laryngoscopy. He was hospitalized with a pre-diagnosis of retropharyngeal space infection and underwent a contrast-enhanced neck computed tomography (CT). The CT scan showed an appearance consistent with that of a foreign body with bone density in the retropharyngeal space at C3-4 along with thickening of the retropharyngeal soft tissue. Air was present in the cerebrospinal fluid (CSF) of the cervical area of the medulla spinalis (Figure 1). We were unable to evaluate his neck stiffness objectively due to pain associated with cervical disc hernia. The patient underwent lumbar puncture on the second day of hospitalization due to rapid deterioration of consciousness and a temperature of up to $40{ }^{\circ} \mathrm{C}$. His $\mathrm{CSF}$ appeared xanthochromic, and direct microscopic examination revealed 900 leukocytes $/ \mathrm{mm}^{3}$ (70\% PMNL). No microorganisms were found on CSF gram staining. Compared to blood levels, CSF glucose was lower (CSF/blood glucose: $36 / 137 \mathrm{mg} / \mathrm{dL}$ ), and protein level was higher $(160 \mathrm{~g} / \mathrm{dL}$, normal range: 15-45 g/dL). Results of his blood biochemistry tests were as follows: whole blood count: $17.000 / \mathrm{mm}^{3}$ (86\% PMNL), C-reactive protein: $44.2 \mathrm{mg} / \mathrm{dL}$ (normal range: $0-5 \mathrm{mg} / \mathrm{dL}$ ), and sedimentation rate: $62 \mathrm{~mm} / \mathrm{h}$ (normal range: $0-5 \mathrm{~mm} / \mathrm{h}$ ). His brain CT was normal. Intravenous meropenem $3 \times 1 \mathrm{~g}$ antibiotic treatment was started on diagnoses of a foreign body in his retropharyngeal space, retropharyngeal space infection, and meningitis. Reproduction of Achromobacter spp. was observed in his blood culture, but not his CSF culture. However, with the delayed diagnosis it was too late for the medicines to have any effect, and the patient died on the second day of antibiotic treatment.

\section{DISCUSSION}

Retropharyngeal space infections can be lifethreatening and delayed diagnosis can be fatal. ${ }^{[5]}$ These infections show up as thickening of the soft tissue in the retropharyngeal space on lateral neck radiography. ${ }^{[6]}$ Magnetic resonance imaging (MRI) and CT are the most important imaging methods used to establish a final diagnosis in such cases. With MRI or CT, abscesses or cellulitis can be differentiated and foreign bodies can be detected. ${ }^{[7]}$

Retropharyngeal space infections rarely result in epidural abscess or meningitis. ${ }^{[8,9]}$ Extension of infection into the central nervous system can be through hematogenous or direct spread. ${ }^{[10]}$ The infectious agents are often Streptococcus viridans, Staphylococcus aureus, Staphylococcus epidermidis, and Bacteroides spp. ${ }^{[11]}$ Some cases of meningitis following adenoidectomy have been reported but injections into the nasopharynx were found to be the causative factor. ${ }^{[12]}$
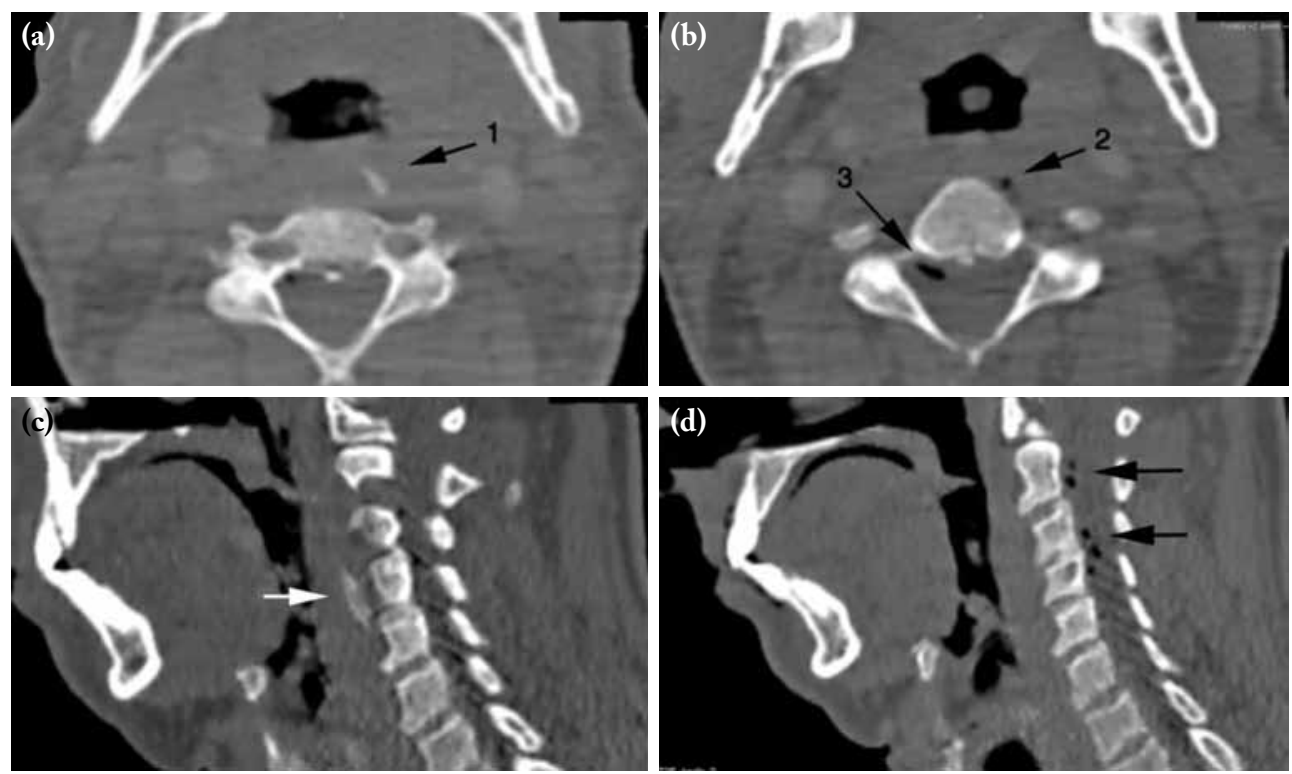

Figure 1. (a, b) Axial computed tomography demonstrates a foreign body (1) in the prevertebral space. The retropharyngeal space is expanded and air is present (2). Air is shown in the subarachnoid space too (3). (c, d) Sagittal computed tomography shows a hyperdense foreign body within the expanded retropharyngeal space and air in the subarachnoid space. 
The development of meningitis following the presence of a foreign body in the retropharyngeal space has rarely been reported in the literature. ${ }^{[10,11,13]}$ In our patient, the diagnosis of meningitis was delayed and it developed secondary to the presence of a chicken bone in the retropharyngeal space. The clinicians were probably misled by the cervical disc hernia and this may have resulted in delayed diagnosis.

In conclusion, delayed diagnosis of foreign bodies in the throat can lead to life-threatening infections. Thus, patients with a history of foreign body, trauma, or surgical operations should be monitored closely for potential complications, and the patients and their relatives must be informed of these complications.

\section{Declaration of conflicting interests}

The author declared no conflicts of interest with respect to the authorship and/or publication of this article.

\section{Funding}

The author received no financial support for the research and/or authorship of this article.

\section{REFERENCES}

1. Shanti RM, Aziz SR. Should we wait for development of an abscess before we perform incision and drainage? Oral Maxillofac Surg Clin North Am 2011;23:513-8.

2. Fogeltanz KA, Pursel KJ. Retropharyngeal abscess presenting as benign neck pain. J Manipulative Physiol Ther 2006;29:174-8.

3. Tannebaum RD. Adult retropharyngeal abscess: a case report and review of the literature. J Emerg Med 1996;14:147-58.

4. Gianoli GJ, Espinola TE, Guarisco JL, Miller RH. Retropharyngeal space infection: changing trends. Otolaryngol Head Neck Surg 1991;105:92-100.

5. Reilly BK, Reilly JS. Retropharyngeal abscess: diagnosis and treatment update. Infect Disord Drug Targets 2012;12:291-6.

6. Virk JS, Pang J, Okhovat S, Lingam RK, Singh A. Analysing lateral soft tissue neck radiographs. Emerg Radiol 2012;19:255-60.

7. Hoang JK, Branstetter BF 4th, Eastwood JD, Glastonbury CM. Multiplanar CT and MRI of collections in the retropharyngeal space: is it an abscess? AJR Am J Roentgenol 2011;196:W426-32.

8. Rodionov NF, Kulagin AIa, Kosolapov IN. Retropharyngeal abscess in an adult patient complicated by purulent meningoencephalitis. Vestn Otorinolaringol 2011;5:68-9. [Abstract]

9. Nakamura A, Odaka M, Hirata K. Case of diabetes mellitus associated with cervical pyogenic spondylitis and meningoencephalitis secondary to retropharyngeal abscess caused by Streptococcus pneumoniae. Brain Nerve 2008;60:571-4. [Abstract]

10. Jeon SH, Han DC, Lee SG, Park HM, Shin DJ, Lee YB. Eikenella corrodens cervical spinal epidural abscess induced by a fish bone. J Korean Med Sci 2007;22:380-2.

11. Tsai YS, Lui CC. Retropharyngeal and epidural abscess from a swallowed fish bone. Am J Emerg Med 1997;15:381-2.

12. Isaacson G, Parke WW. Meningitis after adenoidectomy: an anatomic explanation. Ann Otol Rhinol Laryngol 1996;105:684-8.

13. Maramattom BV, Thomas B. Epidural and brain abscess following Pearl Spot fish bone injury. Neurology 2012;79:484-5. 